\title{
Analysis of splint weaning in temporomandibular disorder patients
}

\author{
Bok Eum Kim¹, Kang Ryul Min², Hyung Tack Kim³, Hyung-Joon Ahn', Seong Taek Kim* \\ 'Department of Orofacial Pain and Oral Medicine, Yonsei University College of Dentistry, Seoul, Republic of Korea \\ 'Department of Biology, Lake Forest College, Illinois, USA \\ ${ }^{3}$ TMJ \& Orofacial Pain Center, Los Angeles, USA
}

Purpose: There are many studies on the indications and efficacy of splint therapy commonly used in patients with temporomandibular disorders (TMD). However, there have been no studies on the splint weaning in terms of the splint use tapering period in relation to symptom improvement of TMD. This retrospective study aims to analyze a proper splint weaning method in patients with TMD based on symptom improvement. Materials and Methods: The authors examined 130 TMD patients with TMJ disorders, masticatory muscle disorders, and clenching/bruxism who had received splint therapy (occlusion stabilization splint, anterior positioning splint) of patients who visited the Department of Orofacial Pain and Oral Medicine at Yonsei University Dental Hospital from 2015 to 2020. They were evaluated according to the method to wean splints. Results: The mean splint therapy period was 29.0 months, during which patients wore splints 7 days a week for 8.4 months, 3 - 4 days a week for 9.5 months, and finally 1 - 2 days a week for 11.1 months (a total of 29.0 months, about 2.5 years). Conclusion: It seems that TMD symptoms can be alleviated and side effects such as occlusal change can be minimized if patients wear a splint 7 days a week for the first 6 months, followed by 3 - 4 days a week for the next 6 to 18 months, and finally 1 - 2 days a week after 18 months. (J Dent Rehabil Appl Sci 2021;37(4):225-31)

Key words: temporomandibular disorders; occlusion stabilization splint; anterior positioning splint

\section{Introduction}

Temporomandibular disorder (TMD) is a common orofacial pain condition and major cause of nondental orofacial pain. ${ }^{1,2}$ Associated clinical problems involve the temporomandibular joint (TMJ), masticatory muscles, adjacent structures and TMJ-related headache conditions. ${ }^{3-5}$ The main signs and symptoms involve TMJ pain, muscle pain, sound (clicking, popping, crepitus), jaw movement limitations, and headache..$^{5-7}$ The etiologies of TMD are not clear, but associated factors include occlusal abnormalities, orthodontic treatment, bruxism, orthopedic

*Correspondence to: Seong Taek Kim

Professor, Department of Orofacial Pain and Oral Medicine, Yonsei University College of Dentistry, Yonsei-ro 50-1, Seodaemun-gu, Seoul, 03722, Republic of Korea

Tel: +82-2-2228-3110, Fax: +82-2-393-5673, E-mail: k8756050@yuhs.ac

Received: September 24, 2021/Last Revision: October 29, 2021/Accepted:

November 23, 2021 instability, psychological/psychobiological factors and macro/microtrauma., ${ }^{8,9}$ TMD is thus a complex and multidimensional disease which if untreated can easily develop into a chronic disease, significantly reducing quality of life. ${ }^{10}$ Treatment options for TMD include occlusal splint therapy, manual therapy, physical therapy, medication, and surgery. ${ }^{11,12}$ Among these, occlusion splint therapy is most commonly used as it decreases TMD symptoms ranging from internal derangements to myofascial pain. ${ }^{6}$ There have been many studies on the indications and efficacy of splint therapy for patients with TMD. ${ }^{5,6,13-18}$ In clinical practice, it seems to be effective in regard-

CopyrightC 2021 The Korean Academy of Stomatognathic Function and Occlusion. (c) It is identical to Creative Commons Non-Commercial License. 
ing to TMD symptoms improvement if patients received splint therapy. But there are not clear standards for the number of days per week and duration of wearing the splint, so it is difficult for clinician to determine how to end splint treatment. In general, abrupt discontinuation of drug during medication treatment may aggravate the existing disease, so it is better to avoid abrupt discontinuation of splint treatment as much as possible. In other words, during splint treatment, it is necessary to gradually reduce the number of splint use ("weaning") and end the treatment. However, there have been no studies on the splint weaning method in terms of tapering period of splint use in relation to TMD symptom improvement. This study was performed to analyze an appropriate splint weaning method in patients with TMD based on efficacy of symptom relief.

\section{Materials and Methods}

One hundred thirty patients who were treated with splint as a conservative treatment of TMD at the Department of Orofacial Pain and Oral Medicine in Yonsei University Dental Hospital from 2015 to 2020 were collected for this study (previous chart

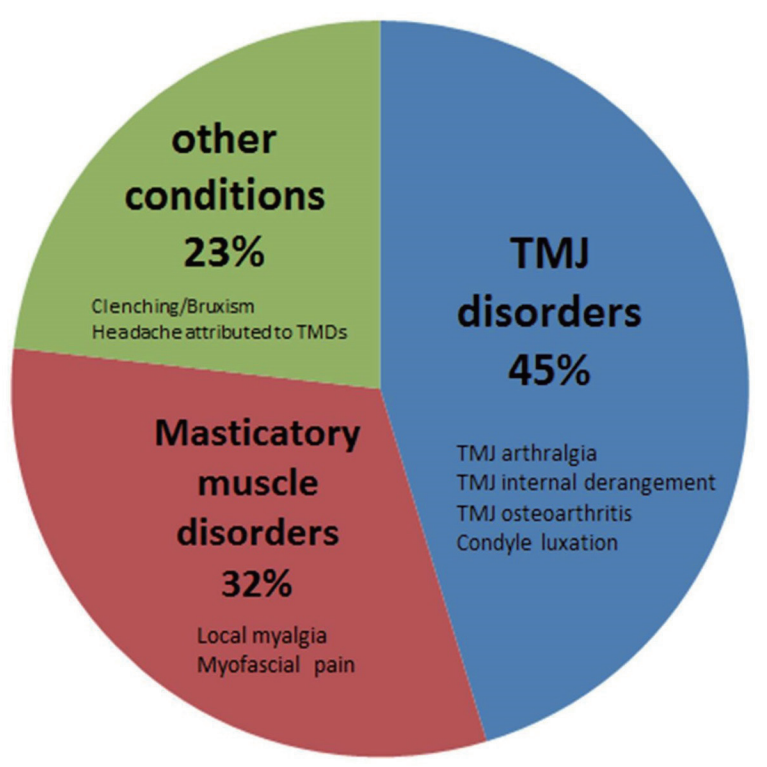

Fig. 1. The clinical diagnosis of temporomandibular disorders (TMD). review). The patients were classified according to the Diagnostic Criteria for TMDs (DC/TMD) axis I. Diagnoses were classified into TMJ disorders, masticatory muscle disorders, and other conditions. TMJ disorders accounted for $45 \%$ of cases, masticatory muscle disorders $32 \%$, and other conditions $23 \%$ (Fig. 1). All patients wore the splint only at night. This study was approved by the IRB committee (IRB number: 2-2019-0017).

\section{Data Variables of Patients}

A total of 130 TMD patients (27 males, $103 \mathrm{fe}$ males, $37.5 \pm 16.5$ years) received splint therapy (occlusion stabilization splint, anterior positioning splint) from 2015 to 2020 (Table 1).

During each visit, patients were evaluated through clinical examination performed by calibrated examiners. The information gathered during these visits was used to assess for TMD signs and symptoms (joint pain, muscle pain, and joint sound). When these subjective symptoms (e.g., visual analog scale (VAS)) and objective signs (e.g., maximal mouth opening (MMO), tenderness) improved, we began weaning, with the patient's consent, the frequency of splint use per week step by step. The specific criteria are as follows:

(1) when pain severity was decreased by $30 \%$ based on VAS.

(2) when the frequency of locking was reduced to $1 / 2$.

(3) when patients open their mouth as much as possible without trismus and pain.

Table 1. Clinical characteristics of the study subjects ( $\mathrm{n}=$ 130)

\begin{tabular}{lc}
\hline \multicolumn{1}{c}{ Variables } & Value \\
\hline Age (years) & 37.5 (SD: 16.5) \\
Sex & \\
$\quad$ Female & $103(79.2 \%)$ \\
$\quad$ Male & $27(20.8 \%)$ \\
Splint & \\
Occlusion stabilization splint (OSS) & $118(90.8 \%)$ \\
Anterior positioning splint (APS) & $12(9.2 \%)$ \\
\hline
\end{tabular}

SD: Standard deviation. 
The months in individual splint treatment were recorded in terms of tapered frequency of use per week. The following are the successive weekly frequencies each patient wore a splint: (1) 7 days a week, (2) 3 - 4 days a week, and (3) 1 - 2 days a week. Exclusion criteria for the study included the following: (1) no regular follow-up visits and (2) irregular period of splint use

\section{Results}

When these subjective symptoms (e.g., visual analog scale (VAS)) and objective signs (e.g., maximal mouth opening (MMO), tenderness) improved, we began weaning, with the patient's consent, the frequency of splint use per week step by step. The mean splint therapy period was 29.0 months (about 2.5 years), during which patients wore splints 7 days a week for 8.4 months, 3 - 4 days a week for 9.5

Table 2. The mean periods (in months) that patients wore splints

\begin{tabular}{cc}
\hline Days of splint use per week & The mean periods $(\mathrm{m})$ \\
\hline 7 & 8.4 \\
$3-4$ & 9.5 \\
$1-2$ & 11.1 \\
\hline
\end{tabular}

m: month. months (a total of 17.9 months, about 1.5 years), and finally 1 - 2 days a week for 11.1 months (a total of 29.0 months, about 2.5 years) (Fig. 2, Table 2).

Fig. 2 correlates the number of days per week wearing the splint for each patient and period of splint use. Patients who wore a splint every day are marked at 7 , patients who wore a splint 3 - 4 days a week are marked at 3.5, and patients who wore a splint 1 - 2 days a week are 1.5. The denser the distribution of dots, the more it can be confirmed that many patients wore the splint in the corresponding period.

\section{Discussion}

The mechanism that the splint reduces the symptoms associated with TMD remains unclear. Various types of splint have been used to treat TMD over the past half century due to their ease of use and broad indications. ${ }^{5,15}$ The splint is widely suggested as an effective treatment modality for patients with signs and symptoms of TMD for a variety of reasons. ${ }^{15}$ The splint can maintain the masticatory muscles in the most relaxed position. ${ }^{13}$ Wearing a splint is generally thought to alter the peripheral sensory input for receptors in the masticatory muscles, periodontal tissues, and oral mucosa. Moreover, the splint can de-

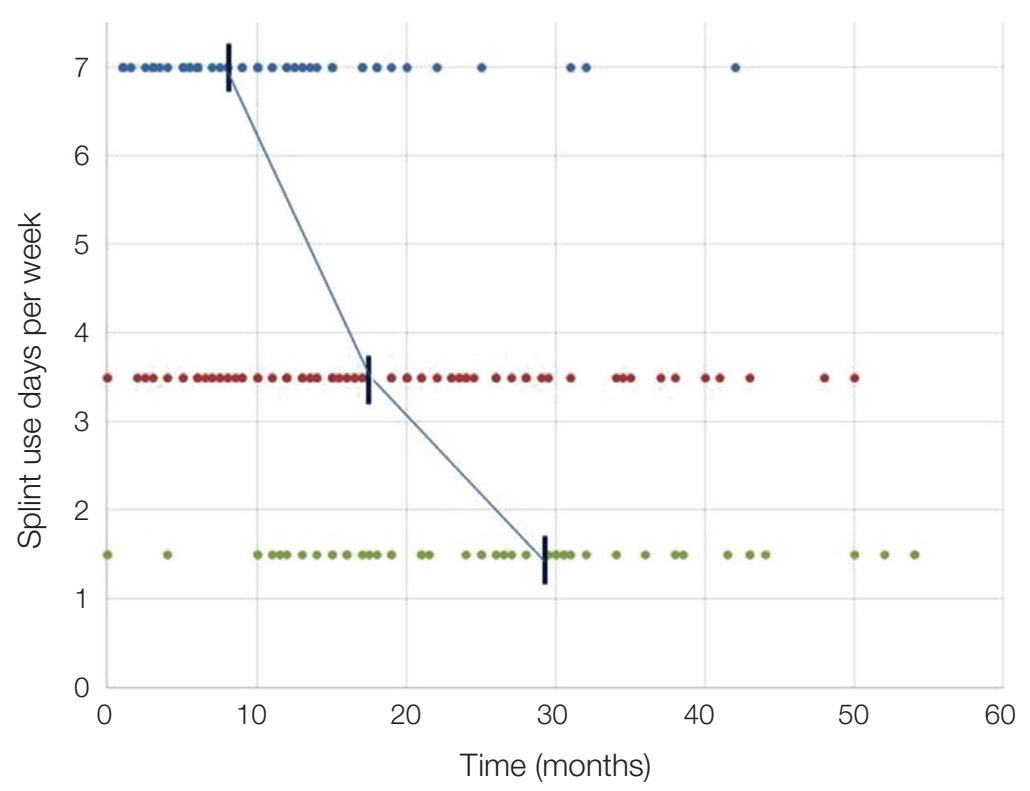

Fig. 2. Individual count of days with splint use per week over time (months). 
crease the intra-articular pressure in the TMJ. ${ }^{2,13,19} \mathrm{It}$ is effective in treating for TMJ arthralgia and myalgia, protecting teeth from attrition, and achieving a stable occlusal contact pattern. It also increases MMO with a $\mathrm{MMO}<45 \mathrm{~mm}$ and reduces VAS pain intensity as well as the frequency of painful episodes for patients with TMJ clicking. ${ }^{5}$ One study found that relative to a placebo group, a group treated with splint could more easily open the mouth without pain and showed a practical treatment effect after 6 months. ${ }^{20}$ However, some side effects can occur including occlusal changes, dental/myofascial discomfort, TMJ pain, xerostomia, and excess salivation. The occlusal changes can be significant. Several studies have described occlusal changes such as palatal inclination of maxillary incisors, labial inclination of the mandibular incisors, slight mesial shift of the mandibular molars and loss of contact between the posterior teeth or posterior open bite (POB). ${ }^{21}$

Based on patients' signs and symptoms, splint therapy must be gradually phased out to prevent this side effect. However, few studies have proposed guidelines for weaning of splint therapy in relation to symptoms of TMD.

This study was conducted to investigate the weaning method and duration of splint therapy in TMD patients. We analyzed the frequency of splint use per week in 130 TMD patients in relation to symptom improvement after splint delivery through a retrospective study (chart review). The authors found that it is possible to minimize splint side effects in TMD patients when proper weaning is applied rather than simple splint delivery. The period of splint therapy is associated with a range of factors, usually related to the amount of time necessary for the retrodiscal tissues to adapt adequately. When the main etiologic factor of TMD is macrotrauma, the duration and success of splint therapy depends on four conditions: acuteness of the injury, extent of the injury, age, and general health of the patient. Patients must be treated individually according to their unique circumstances. In general, when patients wear a splint for shorter periods, fewer complications occur. ${ }^{22}$ In the present study, most patients gradually adapted to the symptoms and conditions. It is desirable to wean the patient from the splint when symptoms have improved. ${ }^{23}$ Based on the weaning method and depending on symptom improvement, the splint therapy consisted of 8.4 months of daily splint use, 9.5 months of 3 - 4 days a week, then 11.1 months wearing the splint 1-2 days a week. Therefore, if TMD patients' symptoms improve, it is recommended that after splint delivery, they should wear the splint 7 days a week for the first 6 months, followed by 3 - 4 days a week for 6 to 18 months, and finally 1 - 2 days a week after 18 months (Fig. 3).

When patients suffer from side effects such as temporary occlusal changes, we prevent permanent occlusal changes by recognizing these symptoms early and weaning frequency of splint use per week or recommending the patients temporarily not wear the splint.

The main limitations of this study are the small sample size and the lack of correlation between side effects and outcomes when splint weaning was not performed properly.

Further studies should include frequency and duration of splint use, the weaning for the type of splint used, and TMD classification as well as a prospective study comparing larger samples of patients in which the weaning was not properly applied.

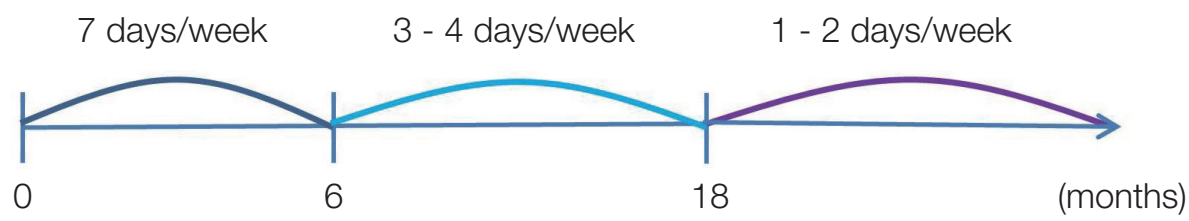

Fig. 3. Recommended frequency and periods (in months) that each patient wear a splint. 


\section{Conclusion}

Conclusions drawn from our retrospective study of splint weaning method in patients with TMD based on symptom improvement are as follows: it is recommended that patients wear a splint 7 days a week for the first 6 months, followed by 3 - 4 days a week for the next 6 to 18 months, and finally $1-2$ days a week thereafter.

\section{Acknowledgements}

This work was supported by the Korea Medical Device Development Fund grant funded by the Korea government (the Ministry of Science and ICT, the Ministry of Trade, Industry and Energy, the Ministry of Health \& Welfare, the Ministry of Food and Drug Safety) (Project Number: KMDF_ PR_20200901_0109, 1711138194).

\section{ORCID}

Bok Eum Kim https://orcid.org/0000-0001-7396-2479 Kang Ryul Min https://orcid.org/0000-0003-4621-7048 Hyung Tack Kim https://orcid.org/0000-0003-3999-4818 Hyung-Joon Ahn https://orcid.org/0000-0001-9669-9781 Seong Taek Kim https://orcid.org/0000-0001-9506-5103

\section{References}

1. Lee HJ, Kim ST. A questionnaire-based study of sleep-wake patterns and sleep quality in a TMJ and orofacial pain clinic. Cranio 2020;38:213-20.

2. Alajbeg IZ, Boric Brakus R, Brakus I. Comparison of amitriptyline with stabilization splint and placebo in chronic TMD patients: a pilot study. Acta Stomatol Croat 2018;52:114-22.

3. Peck CC, Goulet JP, Lobbezoo F, Schiffman EL, Alstergren P, Anderson GC, de Leeuw R, Jensen R, Michelotti A, Ohrbach R, Petersson A, List T. Expanding the taxonomy of the diagnostic criteria for temporomandibular disorders. J Oral Rehabil 2014; 41:2-23.

4. de Resende CMBM, de Oliveira Medeiros FGL, de Figueiredo Rêgo CR, Bispo ASL, Barbosa GAS, de
Almeida EO. Short-term effectiveness of conservative therapies in pain, quality of life, and sleep in patients with temporomandibular disorders: A randomized clinical trial. Cranio 2021;39:335-43.

5. Zhang C, Wu JY, Deng DL, He BY, Tao Y, Niu YM, Deng MH. Efficacy of splint therapy for the management of temporomandibular disorders: a meta-analysis. Oncotarget 2016;7:84043-53.

6. Akbulut N, Altan A, Akbulut S, Atakan C. Evaluation of the $3 \mathrm{~mm}$ Thickness Splint Therapy on Temporomandibular Joint Disorders (TMDs). Pain Res Manag 2018;2018:3756587.

7. Pedroni CR, De Oliveira AS, Guaratini MI. Prevalence study of signs and symptoms of temporomandibular disorders in university students. J Oral Rehabil 2003;30:283-9.

8. Sharma S, Gupta DS, Pal US, Jurel SK. Etiological factors of temporomandibular joint disorders. Natl J Maxillofac Surg 2011;2:116-9.

9. van Grootel RJ, Buchner R, Wismeijer D, van der Glas HW. Towards an optimal therapy strategy for myogenous TMD, physiotherapy compared with occlusal splint therapy in an RCT with therapy-andpatient-specific treatment durations. BMC Musculoskelet Disord 2017;18:76.

10. Furquim BD, Flamengui LM, Conti PC. TMD and chronic pain: a current view. Dental Press J Orthod 2015;20:127-33.

11. Song YL, Yap AU. Outcomes of therapeutic TMD interventions on oral health related quality of life: A qualitative systematic review. Quintessence Int 2018;49:487-96.

12. Armijo-Olivo S, Pitance L, Singh V, Neto F, Thie N, Michelotti A. Effectiveness of Manual Therapy and Therapeutic Exercise for Temporomandibular Disorders: Systematic Review and Meta-Analysis. Phys Ther 2016;96:9-25.

13. Al-Ani Z, Gray RJ, Davies SJ, Sloan P, Glenny AM. Stabilization splint therapy for the treatment of temporomandibular myofascial pain: a systematic review. J Dent Educ 2005;69:1242-50.

14. Lin SL, Wu SL, Ko SY, Yen CY, Yang JW. Effect of Flat-Plane Splint Vertical Thickness on Disc Displacement Without Reduction: A Retrospective Matched-Cohort Study. J Oral Maxillofac Surg 
2017;75:1627-36.

15. Klasser GD, Greene CS. Oral appliances in the management of temporomandibular disorders. Oral Surg Oral Med Oral Pathol Oral Radiol Endod 2009;107:212-23.

16. He S, Wang S, Song F, Wu S, Chen J, Chen S. Effect of the use of stabilization splint on masticatory muscle activities in TMD patients with centric relation-maximum intercuspation discrepancy and absence of anterior/lateral guidance. Cranio 2021;39: 424-32.

17. Zhu H, He D, Yang Z, Song X, Ellis E 3rd. The effect of disc repositioning and post-operative functional splint for the treatment of anterior disc displacement in juvenile patients with Class II malocclusion. J Craniomaxillofac Surg 2019;47:66-72.

18. Kuzmanovic Pficer J, Dodic S, Lazic V, Trajkovic G, Milic N, Milicic B. Occlusal stabilization splint for patients with temporomandibular disorders: Metaanalysis of short and long term effects. PLoS One 2017;12:e0171296.

19. Nitzan DW. Intraarticular pressure in the functioning human temporomandibular joint and its alteration by uniform elevation of the occlusal plane. J Oral Maxillofac Surg 1994;52:671-9.

20. Vrbanovic E, Alajbeg IZ. Long-term Effectiveness of Occlusal Splint Therapy Compared to Placebo in Patients with Chronic Temporomandibular Disorders. Acta Stomatol Croat 2019;53:195-206.

21. Perez CV, de Leeuw R, Okeson JP, Carlson CR, Li HF, Bush HM, Falace DA. The incidence and prevalence of temporomandibular disorders and posterior open bite in patients receiving mandibular advancement device therapy for obstructive sleep apnea. Sleep Breath 2013;17:323-32.

22. Okeson JP. Management of temporomandibular disorders and occlusion. 7th ed. St. Louis; Elsevier; 2013. p. 364.

23. Pertes RA, Gross SG. Clinical management of temporomandibular disorders and orofacial pain. Chicago; Quintessence Pub; 1995. p. 65. 


\title{
측두하악장애 환자에서 장치치료 테이퍼링 및 종료시기에 대한 분석
}

\author{
김복음 ${ }^{1}$ 전임의, 민강렬 ${ }^{2}$ 대학생, 김형택 ${ }^{3}$ 전문의, 안형준 ${ }^{1}$ 교수, 김성택 ${ }^{*}$ 교수 \\ ${ }^{1}$ 연세대학교 치과대학 구강내과학교실 \\ ${ }^{2}$ 미국 일리노이 레이크 포레스트 대학 생물학교실 \\ ${ }^{3}$ 미국 로스앤젤레스 턱관절\&안면통증 센터
}

목적: 측두하악장애 환자에게 주로 사용되는 장치 치료의 적응증 및 효과에 대한 연구는 다수 존재하나, 증상 개선에 따 라 장치를 테이퍼링하여 종료하는 방법에 대한 연구는 부족하다. 따라서 본 후향적 연구는 측두하악장애 환자를 대상으 로, 증상 개선에 따라 장치를 테이퍼링하여 종료하는 과정을 고찰하고자 한다.

연구 재료 및 방법: 턱관절 질환, 근막 통증, 이갈이 및 이악물기 등을 주소로 연세대학교 치과대학병원 구강내과를 내원 하여 장치 치료(교합안정장치, 전방위치교합장치)를 시행한 130 명의 환자의 차트 리뷰를 통해 장치 치료를 테이퍼링하여 종료하는 과정을 알아보았다.

결과 : 평균 장치 장착 기간은 29 개월로, 매일 장치를 장착한 기간은 8.4 개월, 일주일에 3 - 4일간 장치를 장착한 기간은 9.5 개월, 일주일에 1 - 2 일간 장치를 장착한 기간은 11.1 개월이었다.

결론: 측두하악장애 환자에서 장치 장착 시 처음 6 개월 간은 매일 장착, 이후 6 개월에서 18 개월 동안은 일주일에 3 - 4일 간 장착, 18 개월 이후부터는 일주일에 1 - 2일간 장착하는 방식으로 테이퍼링하여 장치 치료를 종료할 시 측두하악장애 환자의 증상은 완화시키면서 교합 변화 등의 부작용은 최소화시킬 수 있을 것으로 사료된다.

(구강회복응용과학지 2021;37(4):225-31)

주요어: 측두하악장애; 교합안정장치; 전방위치교합장치

*교신저자: 김성택

(03722) 서울특별시 서대문구 연세로 50-1 연세대학교 치과대학병원 구강내과

Tel: 02-2228-3110 | Fax: 02-393-8076 | E-mail: k8756050@yuhs. ac

접수일: 2021년 9월 24일 | 수정일: 2021년 10월 29일 | 채택일: 2021년 11월 23일 